\title{
Infection of honey bees with acute bee paralysis virus does not trigger humoral or cellular immune responses
}

\author{
Klara Azzami · Wolfgang Ritter · Jürgen Tautz $\cdot$ \\ Hildburg Beier
}

Received: 21 October 2011/ Accepted: 4 December 2011/Published online: 19 January 2012

(C) The Author(s) 2012. This article is published with open access at Springerlink.com

\begin{abstract}
We have studied the responses of honey bees at different life stages (Apis mellifera) to controlled infection with acute bee paralysis virus and have identified the haemolymph of infected larvae and adult worker bees as the compartment where massive propagation of ABPV occurs. Insects respond with a broad spectrum of induced innate immune reactions to bacterial infections, whereas defence mechanisms based on RNA interference play a major role in antiviral immunity. In this study, we have determined that honey bee larvae and adult workers do not produce a humoral immune reaction upon artificial infection with $\mathrm{ABPV}$, in contrast to control individuals challenged with Escherichia coli. ABPV-infected bees produced neither elevated levels of specific antimicrobial peptides (AMPs), such as hymenoptaecin and defensin, nor any general antimicrobial activity, as revealed by inhibition-zone assays. Additionally, adult bees did not generate melanised nodules upon ABPV infection, an important cellular immune function activated by bacteria and viruses in some insects. Challenge of bees with both ABPV and E. coli showed that innate humoral and cellular immune reactions are induced in mixed infections, albeit at a reduced level.
\end{abstract}

Electronic supplementary material The online version of this article (doi:10.1007/s00705-012-1223-0) contains supplementary material, which is available to authorized users.

K. Azzami $\cdot$ J. Tautz $\cdot$ H. Beier $(\bowtie)$

BEEgroup, Biocentre, University of Würzburg,

Am Hubland, 97074, Würzburg, Germany

e-mail: h.beier@biozentrum.uni-wuerzburg.de

W. Ritter

Department of Bee Pathology, CVUA-Animal Health,

79108, Freiburg, Germany

\section{Introduction}

Viral infection is a major burden for all eukaryotic organisms. As a consequence, they possess efficient mechanisms to combat viral infections that differ in vertebrates, insects and plants. For example, vertebrates respond with the induction of cytokines of the interferon family to viral RNAs in infected cells. Insects lack an adaptive immune system. Instead, they rely on the innate immune system, consisting of humoral and cellular immune responses, and the activation of prophenoloxidase by a serine protease cascade [12, 28, 33, 50]. Infection of Drosophila with bacteria or fungi triggers a strong humoral response that is mediated by two conserved signalling cascades, the Toll and Imd pathways, both of which regulate the transcription of target genes with conserved NF- $\kappa$ B-like motifs. Transcription activation results in the synthesis of antimicrobial peptides (AMPs) in the fat body, followed by secretion of peptides into the haemolymph. The cellular immune response is mediated by circulating cells in the haemolymph called haemocytes that phagocytose and encapsulate invading parasites.

The recent sequencing of the honey bee (Apis mellifera) genome [26] revealed that honey bees possess homologues of members of the Toll and Imd pathway implicated in humoral immune responses [21]. Moreover, a number of honey-bee-specific AMPs were biochemically characterized by Casteels-Josson et al. [11], and their in vivo expression was confirmed in bee larvae and adult workers after bacterial challenge [41]. Although a considerable amount of information is available about humoral defence reactions in bees directed against bacterial and fungal infections, antiviral mechanisms in this social insect are not known at all. Studies in the fruit fly Drosophila and in mosquitos (Aedes aegypti and Anopheles gambiae) have 
provided convincing evidence that an intrinsic cell defence mechanism based on RNA interference plays a major role in antiviral immune responses against single-stranded and double-stranded RNA viruses [3, 23, 29, 44, 51, 53, 54, 57], whereas reports about the significance of inducible antiviral reactions are somehow contradictory. Sabatier et al. [43] did not detect any of the known AMPs in the haemolymph of Drosophila flies challenged with drosophila C virus (DCV) (a member of the family Dicistroviridae). Likewise, injection of cricket paralysis virus (CrPV) into the haemocoel of adult Drosophila flies did not trigger the synthesis of specific AMPs that are known to be induced either by the Toll or the Imd signalling pathway, indicating the absence of humoral immune reactions to the two dicistroviruses. On the other hand, when CrPV was injected into isogenic mutants of the Imd signalling cascade, the flies displayed an increased sensitivity to CrPV infection and higher virus loads, suggesting that the Imd pathway is involved in the antiviral immune response, possibly by distinct branches [15]. Additionally, it was demonstrated by Dostert et al. [19] that several genes controlled by the JAK/STAT pathway were specifically up-regulated upon DCV infection. Furthermore, the induction of the Toll pathway has been identified as an important antiviral response in Drosophila upon infection with drosophila X virus [56] and in Aedes aegypti in dengue virus infection [55]. More recent studies have revealed a dual function of a member of the Dicer family. In addition to its involvement in RNA interference, the DExD/H-box helicase Dicer-2 has been shown also to regulate the induction of a protein (Vago) that controls viral load in some tissues of Drosophila [16].

In this report, we have examined the response of honey bee larvae and adult workers upon infection with acute bee paralysis virus (ABPV). This bee virus was originally regarded as a picorna-like virus but has recently been assigned to the new family Dicistroviridae [14]. ABPV has a single-stranded positive-sense polyadenylated RNA genome of 9.491 nucleotides. The genome consists of two open reading frames (ORFs) separated by an intergenic region. ORF1 encodes the non-structural proteins helicase, 3C-protease and RNA-dependent RNA polymerase, while ORF2 encodes four capsid proteins [25; Fig. 1A]. The structure of dicistrovirus capsids shows similarities to vertebrate non-enveloped picornaviruses, but with some intriguing differences [49]. ABPV was discovered as an inapparent infection of adult bees by Bailey et al. [5]. In contrast to the observed low impact of ABPV infections on the survival of bee colonies for many years, shortly after the introduction of the varroa mite (Varroa destructor) to Europe, ABPV was linked to the high mortality of colonies infested with this ectoparasite [24].

Here, we show (i) that bee larvae respond with a sudden deadly collapse after artificial infection with ABPV, accompanied by an extreme retardation of weight gain and a remarkable change of appearance, (ii) that ABPV propagation in larvae and adults can be monitored by observing viral capsid protein accumulation in the haemolymph of infected individuals, and (iii) that neither humoral nor cellular immune responses are induced or markedly suppressed after ABPV infection of bee larvae and adults.

\section{Materials and methods}

Bacterial strains and media

The Gram-negative bacterium Escherichia coli (DSM 682) was obtained from the Deutsche Sammlung von Mirkoorganismen and Zellkulturen GmbH (DSMZ, Braunschweig), and the Gram-positive bacterium Micrococcus flavus was a gift from Dr. U. Rdest (Institute of Microbiology, Biocentre, Würzburg). The E. coli strain was cultivated in NB medium $(5 \mathrm{~g}$ nutrient broth, $5 \mathrm{~g}$ Bacto peptone and $10 \mathrm{~g}$ $\mathrm{NaCl}$ per liter), whereas M. flavus was grown in LB medium (5 g Bacto yeast extract, $10 \mathrm{~g}$ Bacto tryptone and $10 \mathrm{~g} \mathrm{NaCl}$ per liter). All ingredients were purchased from Becton Dickinson (Heidelberg, Germany). For infection experiments, E. coli bacteria were grown to an absorbance of $\mathrm{A}_{550}=0.5\left(\sim 3 \times 10^{8}\right.$ cells $\left./ \mathrm{ml}\right)$. After centrifugation at $5200 \mathrm{rpm}$ for $5 \mathrm{~min}$ (Eppendorf 5417R), cells were washed two times and resuspended in phosphate-buffered saline (PBS) at the desired concentration.

\section{Preparation of ABPV suspensions}

A single highly purified virus suspension prepared at the CVUA laboratory (Freiburg, Germany) served as a source of acute bee paralysis virus (ABPV). For virus propagation, an ABPV suspension was injected into the haemocoel of white-eyed worker pupae of honey bees (Apis mellifera). The infected pupae were maintained in an incubator at $35^{\circ} \mathrm{C}$ for 3 days. Thirty bee pupae were crushed in $40 \mathrm{ml}$ of $0.01 \mathrm{M}$ potassium phosphate buffer, $\mathrm{pH} 7.2$ (PPB), $2 \mathrm{ml}$ diethyldithiocarbamic acid and $1 \mathrm{ml}$ chloroform. The mixture was passed through cotton gauze, centrifuged at $4000 \mathrm{rpm}$ for $30 \mathrm{~min}$ and incubated at $4^{\circ} \mathrm{C}$ for $16 \mathrm{~h}$. The supernatant was centrifuged at $24,000 \mathrm{rpm}$ for $4.5 \mathrm{~h}$ in a Beckman SW41 rotor. The precipitated virus was resuspended in $1 \mathrm{ml} \mathrm{PPB}$, layered on a $10-40 \%(\mathrm{w} / \mathrm{v})$ sucrose gradient and centrifuged at $21,000 \mathrm{rpm}$ for $3 \mathrm{~h}$ in a Beckman SW28 rotor. The virus fraction was recovered, layered on a $30-60 \%(\mathrm{w} / \mathrm{v}) \mathrm{CsCl}$ gradient and centrifuged at 40,000 rpm for $18 \mathrm{~h}$ in a Beckman SW41 rotor. The virus-enriched fraction was dialyzed against PPB. The concentration of ABPV in the purified preparation was $\mathrm{A}_{260}=5.0$, corresponding to 
A

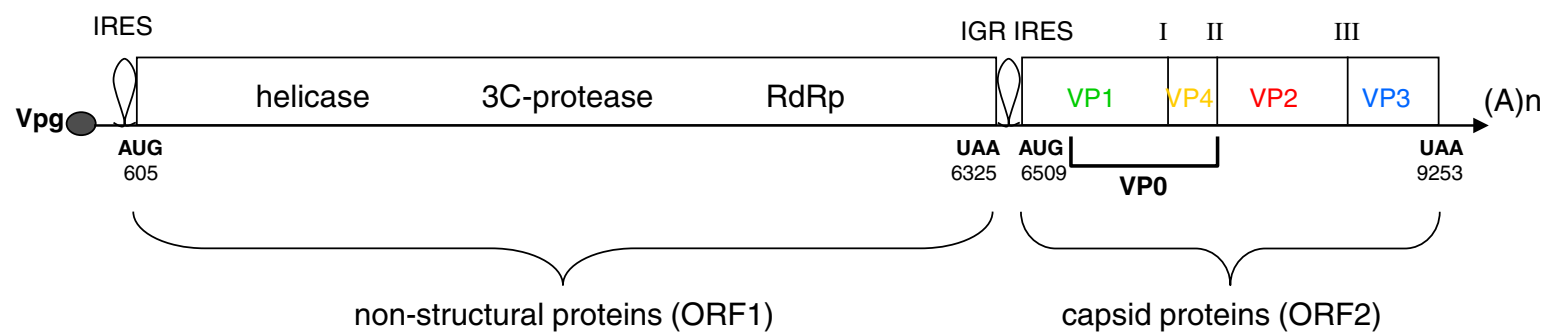

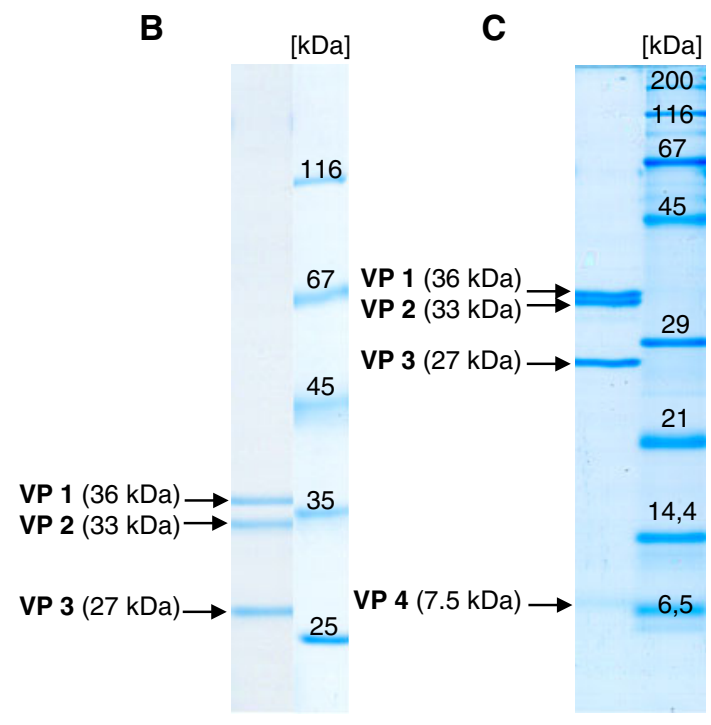

Fig. 1 Genomic mapping of ABPV capsid proteins. (A) Schematic diagram of the genome of ABPV, which is classified as a dicistrovirus. The numbers represent nucleotide positions according to Govan et al. [25]. ORF1 encodes a helicase, a 3C-protease and an RNAdependent-RNA polymerase (RdRp), whereas ORF2 encodes the four capsid proteins. The intergenic region (IGR) between the two ORFs acts as an internal ribosomal entry site (IRES). Roman numbers indicate processing sites. A purified ABPV suspension was separated in a $10 \%(\mathbf{B})$ or $15 \%$ PAA/0.1\% SDS gel $(\mathbf{C})$. The gel was stained with Coomassie blue G250. Arrows specify the viral capsid proteins

$1 \mathrm{mg} / \mathrm{ml}$ [6] and equivalent to about $10^{12}$ particles $/ \mathrm{ml}$ [22]. The $\mathrm{A}_{260} / \mathrm{A}_{280}$ ratio was 1.7. RT-PCR analysis revealed the complete absence of sacbrood virus (SBV) and minor contaminations by deformed wing virus (DWV) in the ABPV preparation.

Origin of honey bee larvae and adults

During the summer seasons of 2008 to 2010, worker honey bee larvae and adult bees were obtained each year from two colonies with sister queens of Apis mellifera carnica maintained in the BEEstation (University of Würzburg). For our studies, only healthy bee colonies were selected that were free of chalk brood and American foulbrood and in which infestation with the Varroa mite had been kept at a low level by a professional beekeeper.
VP1 to VP4. (D) Capsid proteins were excised from the gel, and their peptide composition was determined by MS/MS analysis after in-gel digestion with trypsin. The bracket $(*)$ denotes a peptide fragment derived after cleavage of VP1 with protease V8. The black arrow points to the presumed translation initiation site [39]. Triangles signify putative cleavage sites within the capsid precursor [18, 25]. The amino acid sequence of the capsid precursor protein shown in (D) is almost identical to the ABPV strain "Germany 2" (gil19068035) described by Bakonyi et al. [7]. Underlined amino acids indicate variable positions (colour figure online)

In vitro rearing of worker bee larvae and septic wounding

Larvae were collected from a comb with a special grafting tool and transferred to a 24-well tissue culture plate filled with $300 \mu \mathrm{l}$ of basic diet, consisting of $4.2 \mathrm{~g}$ freeze-dried royal jelly powder, $0.6 \mathrm{~g}$ fructose, $0.6 \mathrm{~g}$ glucose, $0.2 \mathrm{~g}$ Difco yeast extract and $14.4 \mathrm{ml}$ sterile deionised water according to Peng et al. [40]. The larvae were maintained in an incubator (Memmert, $\mathrm{HCP} 108$ ) at $35{ }^{\circ} \mathrm{C}$ and $70 \%$ relative humidity. Each day, they were transferred to new tissue culture plates filled with fresh nutrients. As determined previously, larval weight is a useful index of age [41]. For artificial infection with ABPV or E. coli, fourthinstar larvae with an average weight of $40-60 \mathrm{mg}$ were employed. The larvae were injected dorsally with either 
$1 \mu \mathrm{l}$ of phosphate-buffered saline (PBS) or with $1 \mu \mathrm{l}$ of appropriate amounts of E. coli cells and ABPV particles as described [41] and as indicated in the legend to figures.

In vitro challenge of adult bees with viruses and bacteria

Freshly emerged bees were obtained from a caged comb placed in an incubator at $35{ }^{\circ} \mathrm{C}$ about 20 days after the deposition of eggs by a queen confined on a comb without brood. For each series of experiments, the collected young worker bees were divided in 4 to 6 groups, one of which was kept as an untreated control group. The remaining bees were anesthetized by chilling on ice, and subsequently, volumes of $1 \mu \mathrm{l}$ of buffer (PBS), bacteria (E. coli) or virus $(\mathrm{ABPV})$ were injected laterally between the second and the third tergit into the haemocoel. For injection, disposable calibrated (1-5 $\mu \mathrm{l})$ glass capillaries (Servoprax, Hartenstein, Würzburg) with fine tips were utilized. The bees of each group (10 to 20 individuals) were kept in small metal boxes supplied with $45 \%(\mathrm{w} / \mathrm{v})$ sucrose solution in an incubator at $35{ }^{\circ} \mathrm{C}$ until haemolymph collection.

\section{Haemolymph collection}

At the indicated times after septic and aseptic wounding, all challenged larvae or adult bees were bled by puncturing the abdomen with a fine-tipped glass capillary (see above). The collected haemolymph was transferred to reaction tubes containing mixtures of N-phenylthiourea (PTU) and aprotinin as described [41]. The samples were kept at -20 ${ }^{\circ} \mathrm{C}$ until further analysis.

\section{Inhibition-zone assay}

An aliquot $(0.2 \mathrm{ml})$ of a fresh overnight bacterial culture was spread onto agar plates $(\varnothing 9 \mathrm{~cm})$ containing NB or LB medium. The test bacteria were either E. coli 682 (Gramnegative) or M. flavus (Gram-positive). As soon as the bacterial layer had been adsorbed, $1.5 \mu \mathrm{l}$ of undiluted haemolymph samples were applied as a droplet onto the plates with a pipette tip. After $24 \mathrm{~h}$ of incubation in an incubator at $37{ }^{\circ} \mathrm{C}$, the clear zones of inhibition were documented by photography against a dark background.

Assays for nodulation reactions

We assessed nodule formation in adult bees (ten individuals per group) at 6 and $24 \mathrm{~h}$ after injection with $E$. coli cells and ABPV particles, respectively. A total of three series of experiments were carried out. Before analysis, the bees were embedded in paraffin (Histosec, Merck, Germany). The dorsal abdominal tergits were carefully removed, and the melanised, darkened nodules were counted under a stereomicroscope (Olympus SZX7). After initial counting, the alimentary canal was removed, and nodules in the remaining internal tissue were also counted.

SDS polyacrylamide gel electrophoresis

One-dimensional gel electrophoresis was carried out in vertical polyacrylamide slab gels containing $0.1 \%$ SDS with a 5\% stacking gel on top of the separation gel [32]. Haemolymph samples (1-1.5 $\mu \mathrm{l})$ were diluted with $2 \times$ concentrated sample buffer, heated for $3 \mathrm{~min}$ at $95{ }^{\circ} \mathrm{C}$ and subjected to electrophoresis at constant voltage $(120 \mathrm{~V})$. As a rule, $10 \%$ and $15 \%$ polyacrylamide gels were run in parallel with the same haemolymph samples. For an even better resolution of small proteins, the PAGE system of Schägger and von Jagow [46] was employed with some modifications [41]. After electrophoresis, gels were first fixed for $30 \mathrm{~min}$ in $0.85 \%$ o-phosphoric acid/20\% methanol followed by colloidal Coomassie blue G250 staining overnight in a solution of Roti ${ }^{\circledR}$-Blue (Roth, Karlsruhe, Germany) and 20\% methanol. Gels were destained in $25 \%$ methanol.

MS analysis and protein identification

Stained protein bands were excised from the gel and subjected to in-gel digestion with trypsin. Protein identification by nano LC-ESI-MS/MS analysis, and an NCBI nr protein database search was performed by Proteome Factory AG, Berlin, Germany.

\section{Results}

Characterization and genomic mapping of ABPV capsid proteins

Phylogenetic analysis of ABPV strains of different geographic origin by RT-PCR assays revealed the close genetic relationship between ABPV samples from different European countries [7]. The ABPV strain from the UK (Fig. 1A) that was employed for genome sequence analysis by Govan et al. [25] served as a reference. First, we established the German origin of the virus sample used in our studies, and then we confirmed and expanded the genomic mapping of ABPV capsid proteins. Separation of the virus preparation in either $10 \%$ or $15 \%$ denaturing polyacrylamide gels revealed a total of four capsid proteins of approximately 36, 33, 27 and $7.5 \mathrm{kDa}$ (Fig. 1B, C) that were numbered VP1 to VP4 in decreasing order of their size [25]. The four protein bands were excised from the gels and characterized as true ABPV capsid proteins by 
subsequent MS/MS analysis. Figure 1D shows a summary of tryptic peptides that were identified in each of the four capsid proteins in a total of five independent analyses. The amino acid sequences revealed that the ABPV strain used in our studies is nearly identical to the Germany 2 strain characterized by Bakonyi et al. [7]. The N-terminal sequences of VP2 and VP3 were recently determined by Edman degradation [25] and are indicated by red and blue arrowheads in Fig. 1D. The smallest capsid protein, VP4, had not yet been mapped within the ORF2 region, but our tryptic peptide analysis of the gel-excised VP4 capsid protein clearly indicated its genomic location between VP1 and VP2 (Fig. 1A, D). The cleavage site between VP1 and VP4 was tentatively assigned to be located between peptide sequences VTMQ and INSK by comparison with putative cleavage sites of related dicistroviruses $[18,52]$. We were unable to identify the $\mathrm{N}$-terminal sequence of VP1 by Edman degradation, possibly because VP1 has a blocked N-terminus. Hence, we could not confirm that initiation of translation of the polyprotein encoded in ORF2 starts at the alanine (position 11, illustrated in Fig. 1D) as suggested by several authors [9, 18, 30, 39]. However, it should be pointed out that digestion of ABPV capsid protein VP1 with protease V8 revealed a long peptide in the N-terminal region of VP1, indicating that initiation of translation starts upstream of the glutamate codon at position 14 (Fig. 1D).

Dose-dependent response of bee larvae and adults to ABPV infection

In the original description of ABPV by Bailey et al. [5], adult honey bees were challenged with the virus in three different ways, i.e., by feeding, spraying, and artificial injection of an $\mathrm{ABPV}$ suspension. The $\mathrm{LD}_{50}$ (number of ABPV particles per bee that would have killed half of the bees in a group after 6 days) was equivalent to about $10^{2}$ when preparations were injected into the haemocoel compared to more than $10^{11}$ particles per bee by feeding and $10^{8}$ to $10^{9}$ particles per bee by spraying, indicating the high virulence of $\mathrm{ABPV}$ upon injection.
We first determined the response of newly emerged adult worker bees to serial dilutions of our ABPV suspension upon application into the haemocoel. As controls, we used uninfected bees and bees that were treated with $10^{5}$ viable $E$. coli cells. We have previously shown that challenge of young adult bees (1-2 days old) with this high dose of $E$. coli cells (i) has no deleterious effect on bees and (ii) results in a pronounced stimulation of the humoral immune response, as deduced from the expression of antimicrobial peptides (AMPs) and immune-responsive proteins [41]. Furthermore, it was demonstrated by Bedick et al. [8] that newly emerged adult workers respond to bacterial challenge with strong nodule formation, indicating that cellular immune reactions are also activated in young bees. Almost all individuals of these two control groups survived the maintenance in small cages up to $48 \mathrm{~h}$, and about $84 \%$ and $94 \%$, respectively, were still alive after $72 \mathrm{~h}$ (Table 1). Dilution of the ABPV suspension by $10^{-7}$ prior to injections of $1-\mu 1$ samples (containing $\sim 10^{2}$ virus particles) did not have a pronounced effect on the survival rate or on the pathological symptoms of the infected bees. They looked healthy even at prolonged culture times ( $\geq 96 \mathrm{~h}$ ). Quite in contrast, injection with $10^{3}$ and $10^{4}$ virus particles had a severe impact on both the pathological effects and the survival rate of infected individuals. None of the bees were alive at $72 \mathrm{~h}$ p.i. (Table 1). Bees were regarded as "dead" when they were motionless and had turned on their backs. Symptoms of beginning paralysis, i.e., trembling of wings and bodies of affected bees occurred between 18 and $48 \mathrm{~h}$, depending on the dilution of ABPV. No or only a few bees survived after the application of $\sim 10^{4} \mathrm{ABPV}$ particles, and about $60 \%$ were still alive after $48 \mathrm{~h}$ upon infection of $\sim 10^{3}$ virus particles (Table 1).

Next, we studied the response of fourth-instar larvae to ABPV infection. At this developmental stage, i.e., four days after hatching, bee larvae have an average weight of 30 to $40 \mathrm{mg}$ and survive aseptic and septic wounding to a great extent [41]. As shown in Table 2, injection of $10^{5}$ E. coli cells resulted in 80 to $90 \%$ survival of bee larvae $24 \mathrm{~h}$ p.i. A similar survival rate was observed if larvae

Table 1 Survival [\%] of newly emerged adult worker bees upon artificial infection with E. coli and ABPV

\begin{tabular}{|c|c|c|c|c|c|}
\hline \multirow[t]{2}{*}{ Time (h) p.i. } & \multirow[t]{2}{*}{ Uninfected $^{\mathrm{a}}$} & \multirow[t]{2}{*}{ E. coli $^{\mathrm{a}} 10^{5}$ cells } & \multicolumn{3}{|l|}{$\mathrm{ABPV}^{\mathrm{a}}$} \\
\hline & & & $10^{4 \mathrm{~b}}$ & $10^{3 \mathrm{~b}}$ & $10^{2 b}$ \\
\hline 24 & $100 \pm 0$ & $99 \pm 1.7$ & $54.3 \pm 27.7$ & $82.7 \pm 30$ & $98.3 \pm 2.9$ \\
\hline 48 & $100 \pm 0$ & $95.3 \pm 4.5$ & $6.3 \pm 6.5$ & $56.7 \pm 24.5$ & $95.3 \pm 4.5$ \\
\hline 72 & $93.7 \pm 3.2$ & $83.7 \pm 3.8$ & 0 & 0 & $91 \pm 6.6$ \\
\hline
\end{tabular}

Each group consisted originally of 25 individuals kept together in small cages in an incubator at $35{ }^{\circ} \mathrm{C}$

${ }^{a}$ The results show the mean \pm standard deviation (SD) of three independent series of experiments

b Number of injected ABPV particles per bee 
Table 2 Survival (\%) of fourth-instar bee larvae 24 h post-injection with E. coli and ABPV

\begin{tabular}{|c|c|c|c|c|c|}
\hline \multirow[t]{2}{*}{ Series of experiment } & \multirow[t]{2}{*}{ Uninfected } & \multirow[t]{2}{*}{ E. coli $10^{5}$ cells } & \multicolumn{3}{|l|}{ ABPV } \\
\hline & & & $10^{3 \mathrm{~b}}$ & $10^{2 \mathrm{~b}}$ & $10^{1 \mathrm{~b}}$ \\
\hline I (2008) & $100(14 / 14)^{\mathrm{a}}$ & $80(12 / 15)$ & $0(0 / 12)$ & $53(8 / 15)$ & $81(13 / 16)$ \\
\hline II (2008) & $91(10 / 11)$ & $83(10 / 12)$ & $0(0 / 17)$ & $39(7 / 18)$ & $75(15 / 20)$ \\
\hline III (2009) & $100(12 / 12)$ & $90(9 / 10)$ & $0(0 / 22)$ & $50(6 / 12)$ & $91(10 / 11)$ \\
\hline Mean \pm SD & $97 \pm 5.2$ & $84.3 \pm 5.1$ & 0 & $47.3 \pm 7.4$ & $82.3 \pm 8.1$ \\
\hline
\end{tabular}

${ }^{a}$ Number of survivors in relation to total number of individuals

b Number of injected ABPV particles per larva

were challenged with $10^{1}$ ABPV particles per larva. No larvae survived injections of $\sim 10^{3}$ ABPV particles, whereas about $50 \%$ of larvae were alive $24 \mathrm{~h}$ after injection of $\sim 10^{2} \mathrm{ABPV}$ particles.

ABPV accumulates in the haemolymph of bee larvae and adults

Young adult worker bees injected with relatively small doses of ABPV (approximately $10^{3}$ virus particles per bee) developed first signs of trembling and paralysis as early as $18 \mathrm{~h}$ post-injection and died one or two days later (Table 1). We have studied the time course of virus propagation by collecting haemolymph samples from adult bees at different times post-injection with different amounts of ABPV particles and have analysed the total protein patterns by SDS-PAGE. In newly emerged worker bees (1-2 days old), apolipophorin (ApoLp)-I and -II (the latter lacking the N-terminal amino acids 1 to 747), transferrin and imaginal disc growth factor 4 (IDGF-4) are prominent haemolymph proteins, whereas expression of vitellogenin is still low at this early developmental stage [41]. Upon infection with ABPV, little change in the overall protein pattern was observed between 6 and $24 \mathrm{~h}$ p.i. as compared to haemolymph samples derived from uninfected and mock-infected (PBS) individuals, with the exception of three novel major proteins that were present in approximately equal amounts and were visible only in samples collected from ABPV-infected bees. The migration of two of these coincided with the ABPV capsid proteins VP2 and VP3, whereas the third one migrated more slowly than the expected capsid protein VP1 (Fig. 2A). We eluted the corresponding protein bands from the gel and confirmed the viral origin of VP2 and VP3 by subsequent MS/MS analysis. The amino acid sequence coverage ranged from $27 \%$ (VP2) to $61 \%$ (VP3) for the viral capsid proteins. Significant amounts of bee-specific proteins that migrated to a position similar to that of VP3 were identified as ferritin 1 (gil110762641) and ferritin 2 (gil66524161). The third virus-specific protein was characterized as a precursor capsid protein composed of VP1 and VP4. This feature explains why we did not detect visible amounts of VP4 in 15\% PAA gels (not shown). MS/ MS analysis of the VP1/VP4 precursor revealed exclusively VP1-derived peptides (up to $31 \%$ sequence coverage) in all analyses, as well as the VP4-specific peptide IGSVAAIFG, but never peptides originating from VP2 or VP3. The three ABPV-derived capsid proteins could be first detected $12 \mathrm{~h}$ p.i. in some individuals challenged with $\sim 10^{4}$ particles and were clearly visible $18 \mathrm{~h}$ and $24 \mathrm{~h}$ p.i. in all bees infected with either $10^{3}$ or $10^{4} \mathrm{ABPV}$ particles (Fig. 2A), corresponding to the first signs of pathological effects in infected bees (Fig. 2B). At prolonged incubation times, the sick bees became extremely desiccated so that it was impossible to collect sufficient haemolymph samples for further protein analysis. Another picture emerged if worker bees were challenged with only $10^{2} \mathrm{ABPV}$ particles. The haemolymph protein pattern remained essentially constant up to $96 \mathrm{~h}$ p.i., and virus-specific capsid proteins could not be detected (Fig. 2C), correlating with a high survival rate of the infected bees (Fig. 2D).

The time course of ABPV multiplication was also studied in haemolymph samples from infected bee larvae from 6 to $24 \mathrm{~h}$ p.i. The haemolymph protein pattern of fourth- and fifth-instar larvae differs considerably from that of young adult bees: in addition to ApoLp-I/ ApoLp-II and transferrin, four classes of hexamerins (i.e., hexamerin 110, hexamerin 70a, hexamerin 70b and hexamerin 70c) and a very-high-density lipoprotein (VHDL) constitute the bulk of larval haemolymph proteins [41]. Upon infection with $\sim 10^{3} \mathrm{ABPV}$ particles per larva, the three capsid proteins VP1/VP4, VP2 and VP3 were detected simultaneously in the haemolymph of infected larvae as early as $9 \mathrm{~h}$ p.i., and their production increased up to $24 \mathrm{~h}$ p.i. No virus-specific capsid proteins were visible in larvae infected with only $10^{1}$ ABPV particles (Fig. 3A), which correlates well with the healthy appearance of these larvae and a high survival rate (Fig. 3B, C). Uninfected larvae and larvae challenged with $10^{1} \mathrm{ABPV}$ particles gained weight from about $45 \mathrm{mg}$ at the time of injection (i.e., fourth instar stage) to about $95 \mathrm{mg}$ per larva upon haemolymph collection at $24 \mathrm{~h}$ p.i. (Fig. 3B). Quite another image emerged if larvae were 


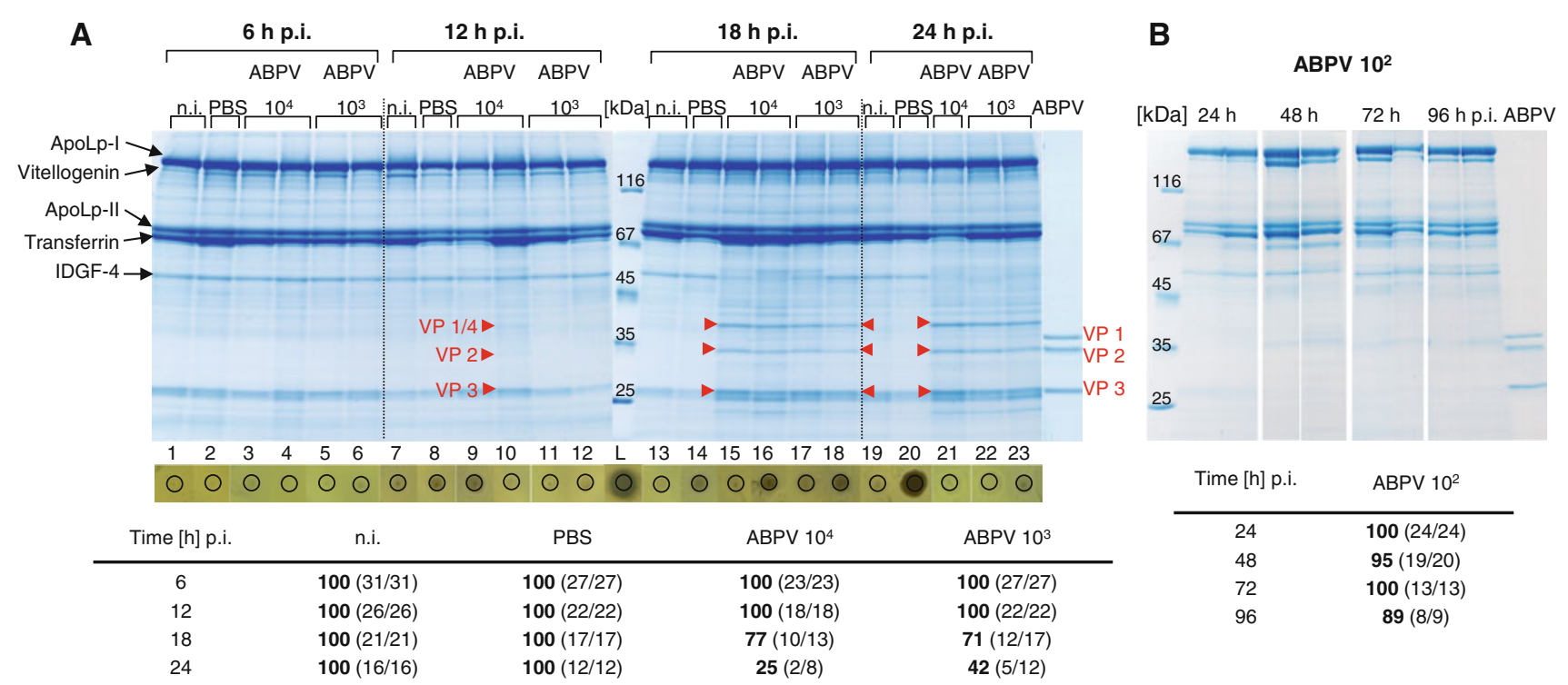

Fig. 2 Time course of ABPV multiplication in the haemolymph of infected adult worker bees. Newly emerged worker bees (1-2 days old) were either kept untreated (n.i.), mock-infected with PBS or challenged with $10^{2}, 10^{3}$ or $10^{4} \mathrm{ABPV}$ particles. Haemolymph samples were collected between 6 and 24 h p.i. (A) or between 24 and $96 \mathrm{~h}$ p.i. (B) from a total of five individuals (replicates) per group followed by protein analysis and inhibition-zone assays. The analyses of 1-2 replicates are shown. Aliquots of $1.5 \mu \mathrm{l}$ (out of $\sim 8 \mu \mathrm{l}$ ) were applied to a $10 \%$ PAA/0.1\% SDS gel, and $1.5-\mu 1$ aliquots of the same sample were applied directly to agar plates together with $M$. flavus as indicator bacteria. As a positive control, lysozyme (L) was used at a

challenged with $\sim 10^{3} \mathrm{ABPV}$ particles. All of them were dead at 24 h p.i. (Fig. 3B) and exhibited a severe weight retardation (49 $\pm 5.7 \mathrm{mg}$ per larva) combined with a change in colour from yellowish-white (Fig. 3B, larvae 13 and 18) to brownish-black (Fig. 3B, larvae 12 and 17) as compared to healthy control larvae. The haemolymph protein pattern likewise changed dramatically. Up to $12 \mathrm{~h}$ p.i., it remained rather unaltered although ABPV had already multiplied to a great extent, but thereafter, a striking change in the overall protein composition could be observed: many proteins that are related to translation, energy metabolism, antioxidant protection or stress response (Table S1) had been induced or up-regulated (Fig. 3A, lane 18). Finally, larval collapse was accompanied by an almost complete degradation of the major haemolymph proteins, such as hexamerin 70a and hexamerin 70b (Fig. 3A, lane 17; Table S1).

Humoral immune response is not induced in bee larvae or adults upon ABPV infection

We have previously studied the defence reactions of honey bee larvae and adults to bacterial infections and have presented evidence that insects at both of these developmental stages respond with a pronounced humoral reaction concentration of $5 \mu \mathrm{g} / \mu \mathrm{l}$. Newly synthesized ABPV-specific capsid proteins are indicated by red arrowheads. As a control, an aliquot of $7 \mu \mathrm{l}$ of the undiluted ABPV suspension $\left(1 \mathrm{mg} / \mathrm{ml} ; \sim 10^{12}\right.$ virus particles $/ \mathrm{ml}$ ) was loaded onto the gel. The survival rate (\%) of ABPVinfected adult bees was monitored throughout the short-time (A) and the long-time (B) experiment. The numbers in brackets represent the number of survivors in relation to the total number of individuals. The total number of bees decreased with prolonged incubation times because five individuals were removed from each group at the indicated times (p.i.) for subsequent protein and inhibition-zone assays (colour figure online)

to challenge with $E$. coli, as documented by the transient synthesis of the three antimicrobial peptides (AMPs) hymenoptaecin, defensin 1 and abaecin [41]. In the present study, we first compared the reactions of bee larvae and adults to single infections with E. coli and ABPV.

Fourth-instar larvae were divided in four groups, each consisting of ten individuals: one group was left untreated (n.i.), one group was mock-infected (PBS), one group was challenged with $10^{5}$ viable $E$. coli cells, and the fourth group was artificially infected with $\sim 10^{3} \mathrm{ABPV}$ particles. All larvae were kept in tissue culture plates filled with fresh nutrients in an incubator at $35{ }^{\circ} \mathrm{C}$ for $24 \mathrm{~h}$. At this time, the haemolymph was collected, and aliquots of the same sample were employed for protein analysis and inhibitionzone assays. As expected, the three known AMPs, i.e., hymenoptaecin, defensin 1 and abaecin, were induced in bee larvae after bacterial infection; however, none of these AMPs were expressed upon challenge with $\sim 10^{3} \mathrm{ABPV}$ particles, as visualized in 15\% PAA / $0.1 \%$ SDS gels (Fig. 4A). Proteins of apparent similar size to hymenoptaecin were eluted from the gel (lane 8; no. 11), and subsequent MS/MS analysis revealed the absence of hymenoptaecin and the presence of two newly induced proteins annotated as heat shock protein $10 \mathrm{kD}$ and thioredoxin-2 (Table S1). In addition, the presence or absence 


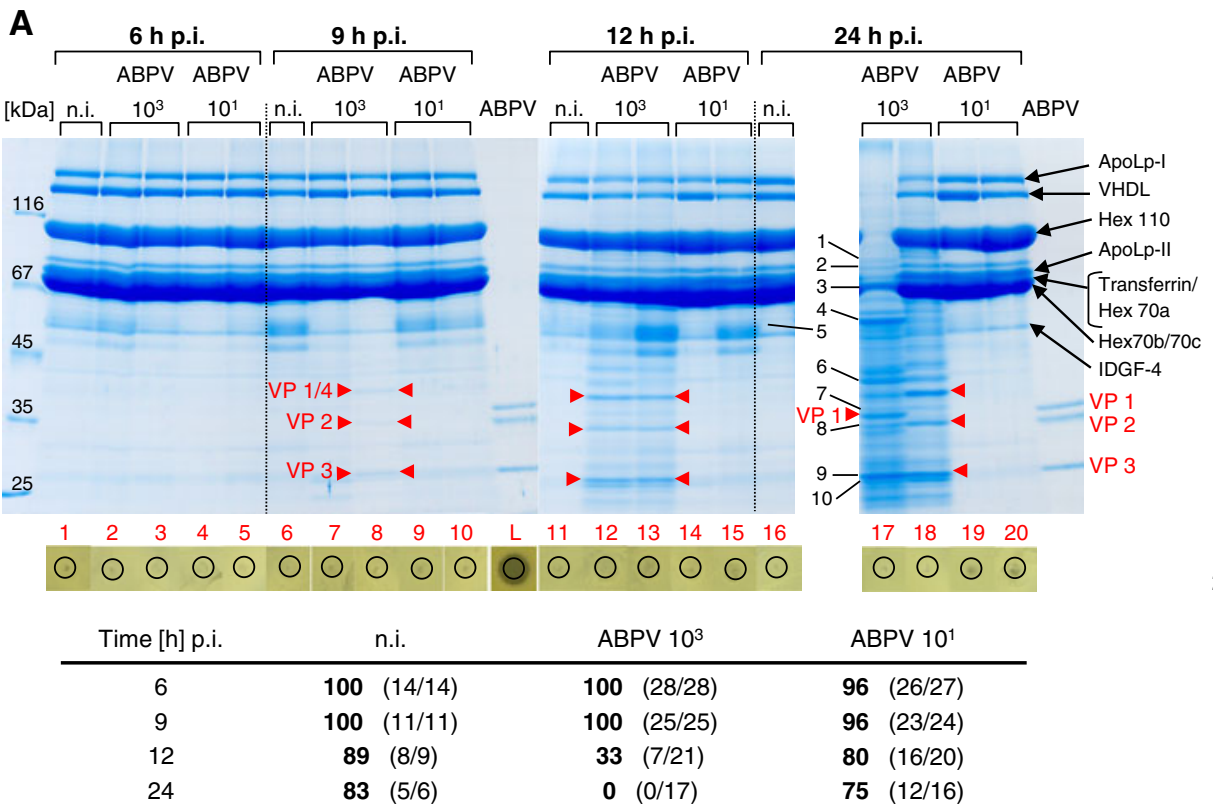

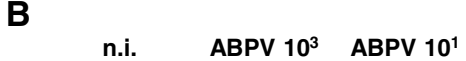

Fig. 3 Time course of ABPV multiplication in the haemolymph of infected bee larvae. Fourth-instar larvae were either left untreated (n.i.) or challenged with $10^{1}$ or $10^{3} \mathrm{ABPV}$ particles. Haemolymph samples were collected between 6 and 24 h p.i. from a total of 3 to 4 individual larvae per group, followed by protein analyses and inhibition-zone assays. The analyses of 1-2 replicates are shown (A). Aliquots of $1 \mu \mathrm{l}$ (out of $\sim 20 \mu \mathrm{l}$ ) were applied to a 10\% PAA/ $0.1 \%$ SDS gel, and $1.5 \mu \mathrm{l}$ of the same sample was applied directly to agar plates together with $M$. flavus as indicator bacteria. Newly synthesized ABPV-specific capsid proteins are indicated by red arrowheads. The development of non-infected (n.i.) and ABPVinfected in vitro cultured larvae up to $24 \mathrm{~h}$ p.i. is shown in (B). Larval weight $(\mathrm{mg})$ is expressed as the mean \pm standard deviation of 3 to 4 larvae. Red Arabic numerals indicate the larvae selected for analysis shown in (A). Dead larvae are indicated by red arrows. Black Arabic numerals (sample 17 in A) signify protein bands that were excised. The proteins identified by MS/MS analysis are listed in Table S1. The survival rate (\%) of ABPV-infected larvae was monitored throughout the incubation time. The numbers in brackets represent the number of survivors in relation to the total number of individuals. The total number of larvae decreased with prolonged incubation times because 3 to 4 individuals were removed from each group at the indicated times (p.i.) for subsequent analysis (colour figure online)
A

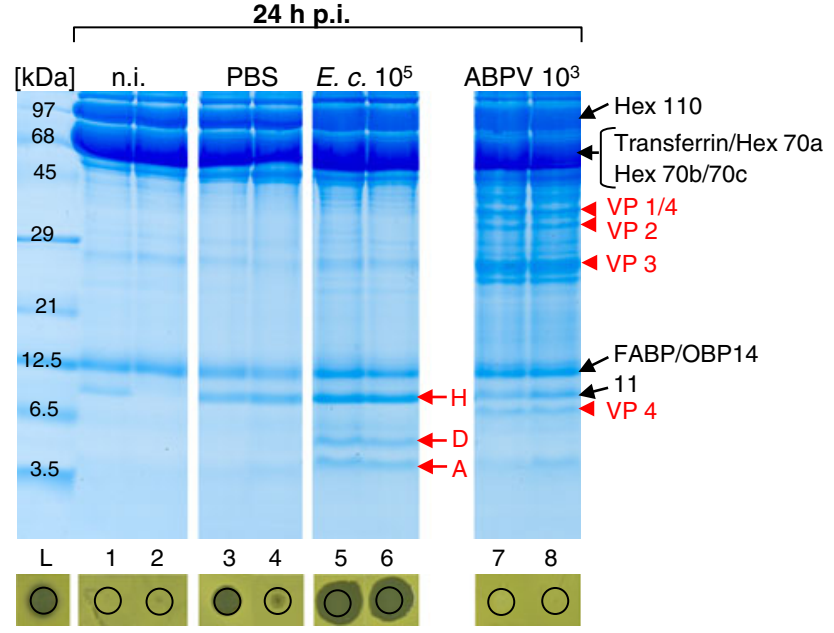

Fig. 4 Comparison of humoral immune responses of bee larvae and adults upon bacterial and viral infections. Fourth-instar larvae (A) or newly emerged worker bees (B) were either left untreated (n.i.), mock-infected with PBS, or challenged with $10^{5}$ E. coli cells or with $10^{3}$ ABPV particles. Haemolymph samples were collected $24 \mathrm{~h}$ p.i., followed by protein analysis and inhibition-zone assays. Aliquots of $1.5 \mu \mathrm{l}$ were applied to $15 \% \mathrm{PAA} / 0.1 \%$ SDS gels containing tricine (A) or no tricine (B). Aliquots of the same samples were applied to
B

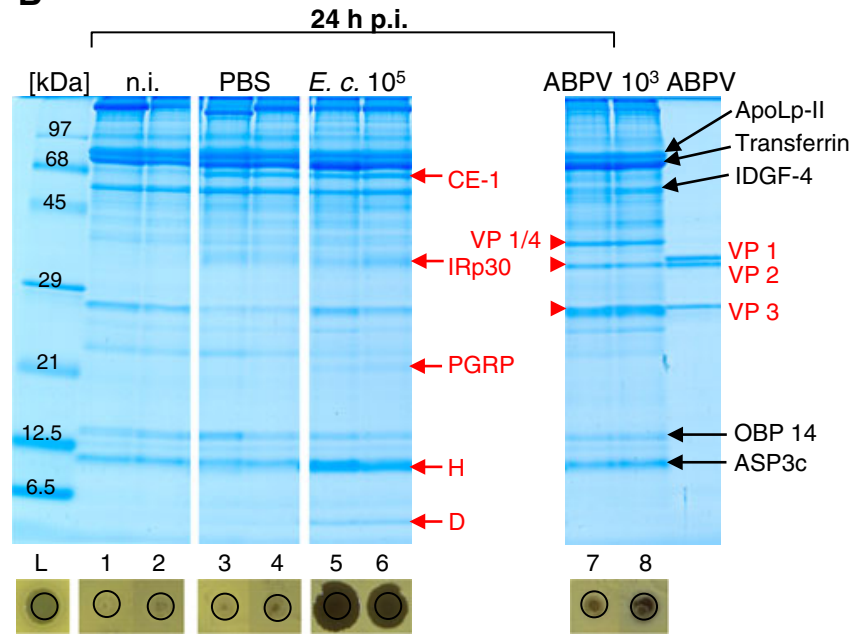

agar plates together with M. flavus as indicator bacteria. Newly synthesized ABPV-specific capsid proteins are indicated by red arrowheads. The AMPs hymenoptaecin (H), defensin 1 (D), abaecin (A) and the immune-responsive proteins carboxylesterase (CE-1), IRp30 and peptidoglycan recognition protein-S2 (PGRP) induced upon bacterial infection [41] are marked by red arrows. The corresponding bands were excised from the gels, and the proteins were identified by subsequent MS/MS analysis (colour figure online) 
of AMPs in haemolymph samples was evaluated in the inhibition-zone assay. Employing M. flavus as Grampositive test bacteria revealed no antimicrobial activity in the haemolymph collected from uninfected or ABPVinfected larvae, whereas large inhibition zones developed after application of samples (no. 5 and 6) derived from larvae challenged with E. coli (Fig. 4A). Similar results were obtained if the Gram-negative E. coli were used as test bacteria in the inhibition-zone assay (not shown). It should be noted that aseptic wounding with PBS sometimes resulted in weak transient synthesis of AMPs, as described previously [41].

Next, we compared the response of adult bees to single infections with $E$. coli and ABPV. Newly emerged worker bees were likewise divided in four groups, each consisting of 20 individuals. They were kept in small cages and placed in an incubator at $35^{\circ} \mathrm{C}$ after artificial infection. Haemolymph samples were collected $24 \mathrm{~h}$ p.i. and utilized for proteome analysis and inhibition-zone assays. Adult bees reacted to challenge with $10^{5} \mathrm{E}$. coli cells with the synthesis of the known AMPs hymenoptaecin and defensin1, as seen in the corresponding haemolymph samples separated in a $15 \%$ PAA/0.1\% SDS gel (Fig. 4B). It should be mentioned that abaecin is not visible in this particular gel. In the haemolymph of adult bees, the chemosensory protein ASP3c is present in all individuals. Since it co-migrates to almost the same position as hymenoptaecin (Fig. 4B, lanes 7 and 8), we excised the corresponding protein bands and confirmed the absence of induced hymenoptaecin upon ABPV infection by subsequent MS/MS analysis. Furthermore, three large immune-responsive proteins were up-regulated upon injection with bacteria and, occasionally, with buffer. The three proteins were identified previously as peptidoglycan recognition protein-S2 (PGRP-S2), a member of the carboxylesterase family (CE-1), and a novel leucine-rich repeat protein termed IRp30 [1, 41]. None of the small antimicrobial peptides or large immune-responsive proteins was induced in adult bees after challenge with $10^{3}$ ABPV particles. Instead, the only new components expressed to a large extent in ABPV-infected bees were the ABPV-specific capsid proteins VP1/VP4, VP2 and VP3. The overall absence of AMPs in adult bees $24 \mathrm{~h}$ after ABPV infection was confirmed in the inhibition-zone assay (Fig. 4B) and in time course experiments shown above (Fig. 2A). In contrast to larval haemolymph, samples originating from adult bees sometimes resulted in inhibition zones that looked brownish in the area where the sample was applied to the agar plate (e.g., Fig. 4B, sample 8) but could be clearly distinguished from "positive" controls (e.g., Fig. 4B, samples 5 and 6). The dark staining possibly results from the production of melanin. Phenoloxidase inhibitors such as phenylthiourea and aprotinin added to the collected haemolymph samples had no significant effect on this phenomenon.
Challenge of young adult worker bees with ABPV does not evoke nodulation reactions

Nodulation is a cellular immune reaction to bacterial infection in many insects that involves interactions between circulating haemocytes and bacteria [27] and is also involved in responses to some viral infections [10, 20]. It was recently demonstrated by Bedick et al. [8] that this specialized cellular defence reaction is expressed in newly emerged worker bees artificially infected with freeze-dried bacteria (i.e., Serratia marcescens). We have made similar observations with adult bees challenged with viable $E$. coli cells but found that bee larvae responded to bacterial infection with a very weak nodulation reaction (unpublished observation). We injected $E$. coli cells into the haemocoel of young adult workers and assessed the formation of nodules at selected times post-injection. The first melanised nodules were visible at $2 \mathrm{~h}$ p.i., reached a maximum of approximately 100 nodules per bee at $6 \mathrm{~h}$ p.i., and thereafter, the total number of visible nodules remained constant up to $48 \mathrm{~h}$ p.i. Figure $5 \mathrm{~A}$ shows a typical image of nodule formation $24 \mathrm{~h}$ after injection of $10^{4}$ viable $E$. coli cells. It can be seen that the abdominal tergites have been removed and the haemocoel is exposed. Most melanised nodules are attached along the dorsal vessel and the tracheal system. However, in three independent series of experiments, we did not observe any nodules at any time post-injection of $10^{3}$ or $10^{4} \mathrm{ABPV}$ particles into the haemocoel of freshly emerged worker bees (Fig. 5B), suggesting that this cellular defence reaction is not mediated by ABPV in bees.

Innate immune responses are expressed in bees simultaneously infected with ABPV and E. coli

As reported above, a prominent humoral immune response was not induced in bee larvae or adults upon ABPV infection (Figs. 2, 3, 4), nor did adult worker bees respond with a nodulation reaction to challenge with ABPV (Fig. 5B). Hence, we asked the question whether innate immune responses are generally suppressed in infected individuals as a consequence of ABPV propagation. We carried out a series of experiments with bee larvae and adults challenged with only $E$. coli or ABPV or with both pathogens together (Fig. 6).

AMPs were induced upon $E$. coli infection of larvae as early as $6 \mathrm{~h}$ p.i. (not shown). Longer incubation times of 12 and $24 \mathrm{~h}$ p.i. resulted in enhanced expression of antimicrobial activity as deduced by increased production of hymenoptaecin and defensin1 and the enlargement of inhibition zones (Fig. 6A). No evidence for the production of AMPs could be detected in ABPV-infected larvae at any time post-injection (Figs. 3A, 6A). Simultaneous infections 

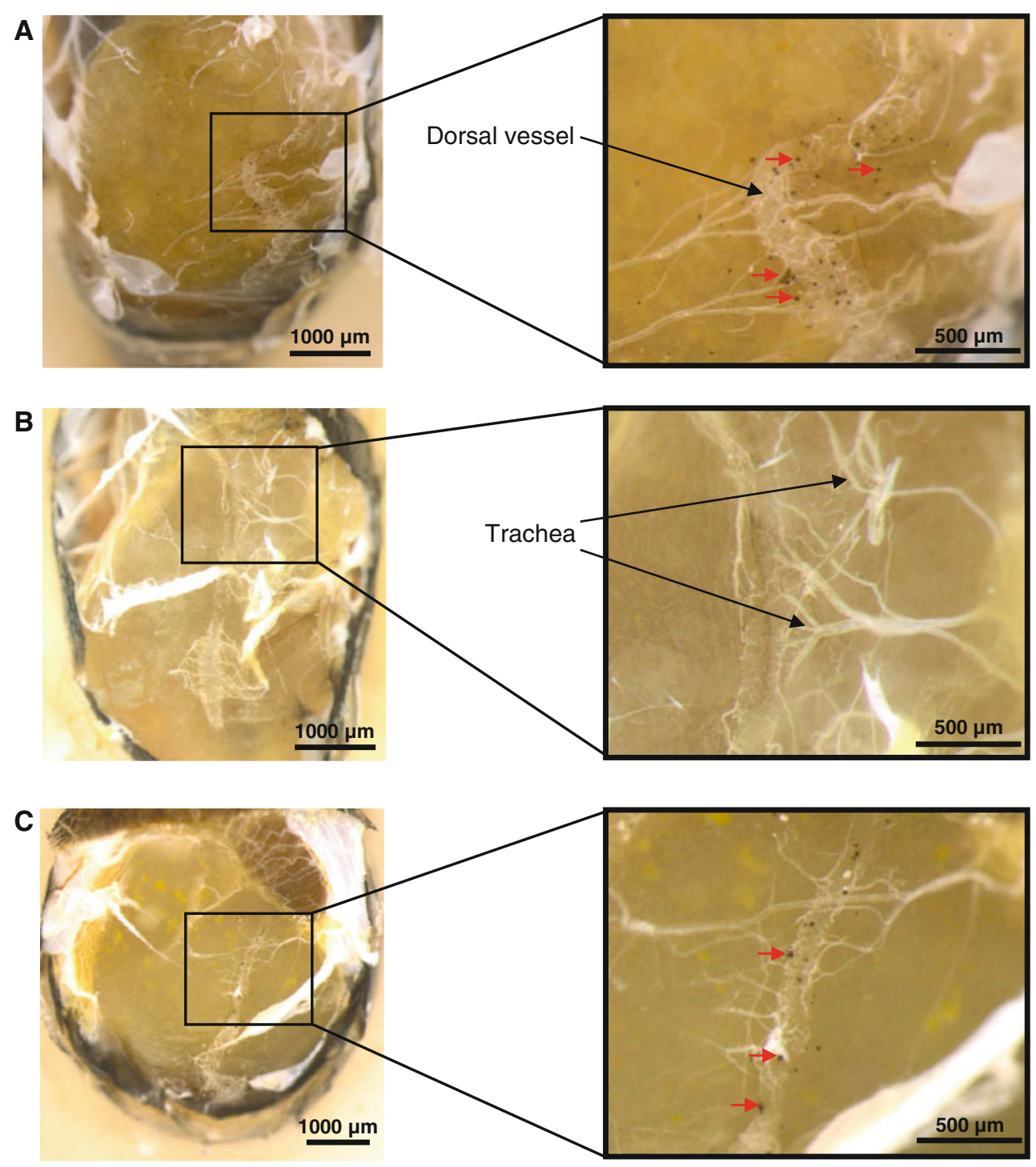

Fig. 5 Comparison of cellular immune responses of adult worker bees upon bacterial and viral infections. Newly emerged worker bees were challenged with $10^{4}$ viable $E$. coli cells (A), $10^{3} \mathrm{ABPV}$ particles $(\mathbf{B})$, or with a mixture of the two pathogenic components consisting of $10^{4}$ E. coli cells and $10^{3} \mathrm{ABPV}$ particles (C). Groups of 10 individuals were kept in small cages for $24 \mathrm{~h}$ p.i. in an incubator at $35^{\circ} \mathrm{C}$. Then, the abdominal tergites of the bees were removed, and the

of larvae with E. coli and ABPV did not suppress the induction of a humoral response up to $12 \mathrm{~h}$ p.i., as indicated by the presence of AMPs in the inhibition-zone assay (Fig. 6A, samples 7-9). However, very little antimicrobial activity could be detected in mixed infections at prolonged incubation times up to $24 \mathrm{~h}$ p.i. (Fig. 6A, samples 15 and 16). These observations were made repeatedly in a total of three independent series of experiments. Multiplication of ABPV in larvae along with simultaneous $E$. coli infection proceeds as in single infections, as revealed by the massive production of ABPV-specific capsid proteins (Fig. 6A, haemocoel was inspected for the presence of melanised nodules, which are indicated by red arrows. The average number of nodules was $108 \pm 14(\mathbf{A}), 0(\mathbf{B})$ and $52 \pm 24(\mathbf{C})$, respectively, expressed as the mean \pm standard deviation of five examined bees. Photomicrographs were made with an Olympus SZX7 stereomicroscope equipped with an Olympus UC30 camera. Magnification was $25 \times$ for the complete abdomen and $75 \times$ for the detailed view (colour figure online)

lanes 15 and 16), but the onset of visible virus propagation is delayed in mixed infections.

Simultaneous infections of newly emerged adult worker bees with $10^{3} \mathrm{ABPV}$ particles and $10^{4} \mathrm{E}$. coli cells revealed features that were similar but not identical to those observed in larvae. We did not detect a reduction in the overall antimicrobial activity in the inhibition-zone assay up to $24 \mathrm{~h}$ p.i. (Fig. 6B, samples 6 and 7), but we did observe a delay in ABPV propagation (Fig. 6B). A slightly different picture emerged if we injected $10^{4}$ ABPV particles and $10^{5} \mathrm{E}$. coli cells simultaneously into young adult 
A

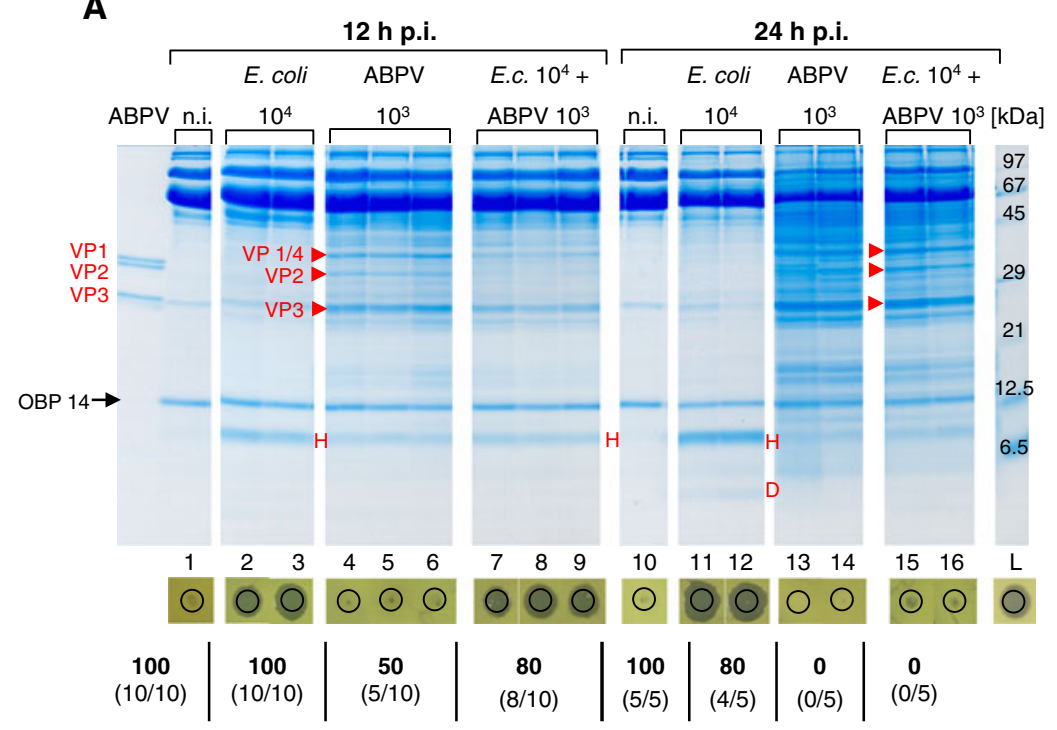

B

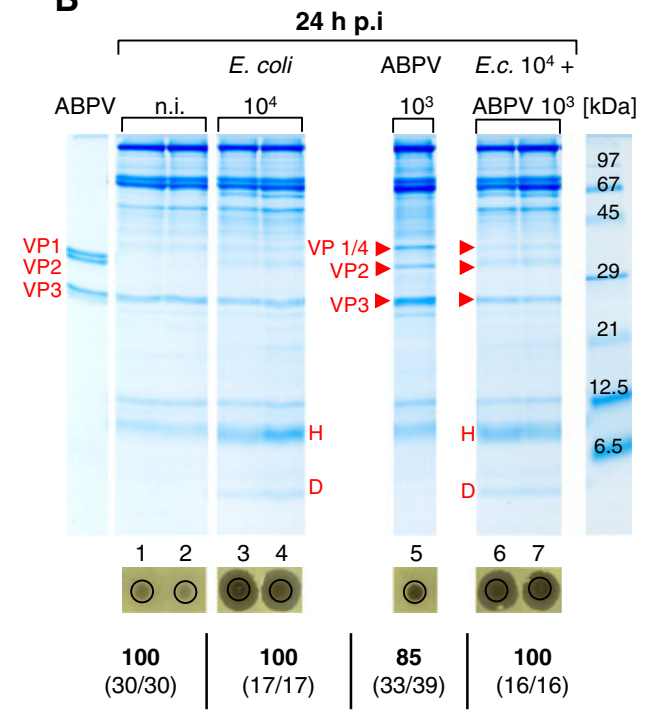

Fig. 6 Responses of bee larvae and adults upon simultaneous infection with $\boldsymbol{E}$. coli and ABPV. Fourth-instar larvae (A) and newly emerged worker bees (B) were left untreated (n.i.), challenged separately with $10^{4} \mathrm{E}$. coli cells and with $10^{3} \mathrm{ABPV}$ particles or challenged with a mixture of $10^{4}$ E. coli cells and $10^{3}$ ABPV particles.

worker bees. Under these experimental conditions, we did not observe a delay in ABPV propagation, but we did observe a reduction in antimicrobial activity (not shown).

As shown above, adult worker bees responded with the formation of nodules upon E. coli infection (Fig. 5A), whereas this reaction was not initiated after ABPV infection (Fig. 5B). Simultaneous injection of E. coli and ABPV into the haemocoel of young worker bees did not suppress the nodulation reaction completely but resulted in a reduced number of nodules detected at 24 h p.i. (Fig. 5C).

\section{Discussion}

In connection with the recent expansion of the ectoparasitic mite Varroa destructor in honey bee colonies, a newly acquired virulence of several bee viruses belonging to the family Dicistroviridae has been observed worldwide [24]. We have focused our interest on acute bee paralysis virus (ABPV), one of about 18 bee viruses identified so far $[2,13]$. ABPV shares some antigenic and sequence similarities with Kashmir bee virus (KBV) and Israeli acute paralysis virus (IAPV), and together they form a distinct subgroup within the family Dicistroviridae [9, 17, 18, 35]. Three major features are of general relevance concerning viral infections: (i) the site of viral propagation within infected individuals, (ii) the routes of viral transmission, and (iii) the defence mechanisms initiated upon viral infection.

We have identified the haemolymph of infected bee larvae and of adults as the source of massive ABPV
Haemolymph samples were collected at the indicated times, followed by protein analysis and inhibition-zone assays. Survival rates [\%] are indicated below. Newly synthesized ABPV-specific capsid proteins are indicated by arrowheads. $\mathrm{H}=$ hymenoptaecin, $\mathrm{D}=$ defensin 1

propagation and were able to monitor virus multiplication in vivo in the natural host by observing capsid protein synthesis via gel electrophoretic analysis (Figs. 2A, 3A). The translation of ORF2 from an internal ribosomal entry site (Fig. 1A) yields a precursor polypeptide of $\sim 104 \mathrm{kDa}$ (Fig. 1D) that has to be processed into functional capsid units by three proteolytic steps (indicated as I, II and III in Fig. 1A), two of which (I and III) are most likely generated by the virus-encoded $3 \mathrm{C}$ protease. This chymotrypsin-like cysteine protease cleaves right after a conserved glutamine (Q) residue $[18,42]$. The structural motif of the third cleavage site separating VP4 from VP2 (cleavage site II) is highly conserved in all dicistroviruses [52]. Yet, the corresponding proteolytic activity is not known. It has been proposed that this site is processed autocatalytically inside the mature virion $[34,49]$ or that an unknown host-cell activity is involved. We have detected a single precursor polypeptide in ABPV-infected bee larvae and adults that is composed of VP1 and VP4 and has been designated as VP0 (Fig. 1A) by analogy to picornaviruses [31]. This capsid precursor is expressed at about the same time and at about equivalent amounts as the two capsid protein units VP2 and VP3 (Figs. 2A, 3A), indicating almost simultaneous cleavages of the polyprotein precursor at processing sites II and III. Infrequently, we observed the separate capsid protein units VP1 and VP4 in ABPV-infected larvae at $24 \mathrm{~h}$ p.i. (Figs. 3A, 4A), implying that processing step $I$ is a late event. This processing scheme observed in vivo in the haemolymph of ABPV-infected bees differs from that suggested by Tate et al. [49], who determined the first 
three-dimensional crystal structure of an insect picornavirus (i.e., cricket paralysis virus, $\mathrm{CrPV}$ ) and indicated the order of capsid proteins encoded in the precursor as VP2/VP4/VP3/ VP1. This numbering appears to be misleading, because it reflects neither the order of capsid proteins in picornaviruses (VP4/VP2/VP3/VP1), where numbers 1 to 4 refer to the poliovirus capsid proteins in order of decreasing size [31], nor to the actual sizes of CrPV capsid proteins which would result in the genomic order VP2/VP4/VP1/VP3 (AF218039; 35). Tate et al. [49] have proposed that cleavage at site II most likely occurs concurrently with packaging of the viral RNA within the mature virus particle because they found the C-terminus of VP4 to be located in close proximity to the $\mathrm{N}$-terminus of VP3, i.e., within "bonding" distance. There are some reports that support the assumption that cleavage at site II is a late processing event, whereas other studies present data that instead indicate that cleavage at site I occurs late in infection. N-terminal sequencing of capsid proteins obtained from purified immature Plautia stali intestine virus (PsIV) particles revealed that a minor precursor protein of $35 \mathrm{kDa}$ called VP0 had the same N-terminal sequence as VP4, suggesting that VP0 is composed of VP4 and VP2 according to the numbering of PsIV [38, 45]. On the other hand, studies of the propagation of $\mathrm{CrPV}$ and drosophila $\mathrm{C}$ virus (DCV) in Drosophila cells revealed a pattern similar to that observed for the multiplication of ABPV in honey bees. Three major polypeptides were detected early in infected cells, corresponding to two capsid proteins and one viral precursor protein (VP0) that possibly consisted of VP2 and VP4 [36, 37] analogous to VP1/VP4 expressed in bee larvae and adults (Figs. 2, 3).

Newly synthesized ABPV capsid proteins were clearly visible in the haemolymph of infected bee larvae or adults between 9 and $12 \mathrm{~h}$ p.i., and their amount increased rapidly up to $24 \mathrm{~h}$ p.i. (Figs. 2A, 3A). The haemolymph contains several types of cells, called haemocytes, that differ in various insects [50]. However, the prevalent cell type in all insects are plasmatocytes, which are partially responsible for phagocytosis of invading pathogens [28, 33]. Although we cannot completely rule out that ABPV is propagated in the fat body or any other tissue and subsequently released into the haemocoel, we think it more likely that ABPV multiplies in free haemocytes. This assumption is supported by the observation that ABPV capsid proteins (VP0, VP2 and VP3) were highly enriched in the cellular fraction after low-speed centrifugation $(\sim 15,000 \mathrm{~g})$ of the total haemolymph and not in the supernatant. In contrast, AMPs and immune-responsive proteins produced in the fat body after challenge with bacteria were found enriched in the supernatant fraction (not shown). Moreover, it should be noted that we have observed the occurrence of the ABPV-specific capsid precursor VP0 (composed of VP1 and VP4) simultaneously with capsid units VP2 and VP3 in the haemolymph of infected larvae and adult bees (Figs. 2A, 3A). If one excludes the possibility that aberrant virus particles are released to a great extent by any cell type, then the haemocytes remain the likely candidates for ABPV propagation. In adult bees acutely infected with ABPV, the virus accumulates in the brain and hypopharyngeal glands [4]. Since the haemolymph circulates freely through all body sections of the honey bee, ABPV could reach the head after abdominal infections by two means: either by being entrapped in haemocytes or as free virus particles after release from disintegrating cells.

Challenge of insects with microorganisms induces cellular and humoral immune responses. Nodulation is a cellular immune function that is activated by bacteria and fungi [48], and it has been shown that this reaction is also involved in responses to some viral infections. For example, larvae of the endoparasitoid Pimpla turionella (Hymenoptera) and larvae of the greater wax moth Galleria mellonella (Lepidoptera) challenged with bovine herpes simplex virus-1 (BHSV-1) induced nodulation reactions in a dose-dependent manner $[10,20]$. Newly emerged adult bees responded with a pronounced production of melanised nodules after $E$. coli infection (Fig. 5A); however, no nodules at all were detected upon ABPV infection (Fig. 5B), suggesting that this type of cellular immune response is not activated against ABPV in bees. Moreover, our data indicate that honey bee larvae and adults also do not trigger a general humoral immune response upon $A B P V$ infection - in contrast to the reaction observed after challenge with $E$. coli. ABPV-infected individuals did not produce elevated levels of specific AMPs such as hymenoptaecin, and we did not detect any general antimicrobial activity in the inhibition-zone assay (Fig. 4). Expression of hymenoptaecin in bees is mediated by the Imd signalling cascade, as revealed by RNA interference studies [47]. Hence, the absence of hymenoptaecin in ABPVinfected cells implies that the Imd pathway initiating a humoral immune response is not induced upon ABPV infection. These results are consistent with studies carried out by Sabatier et al. [43] and Costa et al. [15], who did not detect any of the known AMPs in the haemolymph of Drosophila flies challenged with DCV or CrPV (two members of the family Dicistroviridae), supporting our finding that viral infections of insects do not induce the same innate immune response as bacterial infections. As mentioned above, the intrinsic defence mechanism based on RNA interference plays a major role in antiviral immunity in insects. Future studies are of utmost importance to reveal the role of RNAi in the antiviral response of honey bees.

The failure to detect AMPs in virus-infected individuals could actually mean that humoral immune responses are suppressed by the virus. To address this question, we have carried out numerous experiments with simultaneous injections of $E$. coli and ABPV into larvae or adult bees (Fig. 6). We observed mutual detrimental effects in mixed 
infections on both levels, i.e., the expression of antimicrobial peptides as well as the onset and extent of ABPV propagation. The impact on either response was dependent to some degree on the injected individual dose of $E$. coli cells and ABPV particles in mixed infections. But we detected antimicrobial activities and specific AMPs in the haemolymph of individuals challenged with both types of pathogens, indicating that the strong humoral immune response induced after bacterial challenge is not suppressed completely by viral infection (Fig. 6).

The high yield of ABPV particles produced in the very first $12 \mathrm{~h}$ p.i. in bee larvae and adults clearly precedes any noticeable responses of the infected individuals either at the molecular level or in the occurrence of pathological symptoms: the overall haemolymph protein pattern remained essentially unchanged in this early infection period, and pathological effects were also not yet visible (Figs. 2, 3). Later on, the responses of sick bee larvae and adults differed strikingly. Protein analysis of haemolymph samples collected from ABPV-infected adult bees revealed no major alterations throughout the entire infection process-apart from the massive synthesis of ABPV capsid proteins (Fig. 2A), whereas in the haemolymph of ABPV-infected larvae a broad spectrum of proteins was induced between 12 and $24 \mathrm{~h}$ p.i., which included various heat-shock proteins (Table S1). Finally, the major larva-specific haemolymph proteins such as hexamerins $70 \mathrm{a}$ and $70 \mathrm{~b}$ were degraded (Fig. 3A; Table S1). The impressive change in the haemolymph protein pattern coincided with a dramatic change in the appearance of ABPV-infected bee larvae (Fig. 3C). The quick and almost simultaneous deadly collapse of bee larvae upon ABPV infection combined with these striking features indicate that in vitro-cultured bee larvae are convenient model organisms for (i) reliable and quick bioassays to test ABPV infectivity, (ii) the study of host-virus interactions, and (iii) the screening of antiviral compounds [22].

Acknowledgments We thank D. Ahrens-Lagast (BEEgroup, Würzburg) for the excellent management of bee colonies. We are grateful to Professor H. J. Gross (University of Würzburg) for critical reading of the manuscript. This project was financially supported by a grant from the "Deutsche Forschungsgemeinschaft", SFB 567, Part A9.

Open Access This article is distributed under the terms of the Creative Commons Attribution Noncommercial License which permits any noncommercial use, distribution, and reproduction in any medium, provided the original author(s) and source are credited.

\section{References}

1. Albert S, Gätschenberger H, Azzami K, Gimple O, Grimmer G, Sumner S, Fujiyuki T, Tautz J, Mueller MJ (2011) Evidence of a novel immune responsive protein in the Hymenoptera. Insect Biochem Mol Biol 41:968-981
2. Allen M, Ball B (1996) The incidence and world distribution of honey bee viruses. Bee World 77:141-162

3. Arjona A, Wang P, Montgomery RR, Fikrig E (2011) Innate immune control of West Nile virus infection. Cell Microbiol. doi: 10.1111/j.1462-5822.2011.01649.x

4. Bailey L, Milne RG (1969) The multiplication regions and interaction of acute and chronic bee-paralysis viruses in adult honey bees. J Gen Virol 4:9-14

5. Bailey L, Gibbs AJ, Woods RD (1963) Two viruses from adult honey bees (Apis mellifera Linnaeus). Virology 21:390-395

6. Ball BV (1985) Acute paralysis virus isolates from honeybee colonies infested with Varroa jacobsoni. J Apic Res 24:115-119

7. Bakonyi T, Grabensteiner E, Kolodziejek J, Rusvai M, Topolska G, Ritter W, Nowotny N (2002) Phylogenetic analysis of Acute bee paralysis virus strains. Appl Environ Microbiol 68:6446-6450

8. Bedick JC, Tunaz H, Nor Aliza AR, Putnam SM, Ellis MD, Stanley DW (2001) Eicosanoids act in nodulation reactions to bacterial infections in newly emerged adult honey bees, Apis mellifera, but not in older foragers. Comp Biochem Physiol Part C 130:107-117

9. Bonning BC, Miller WA (2010) Dicistroviruses. Annu Rev Entomol 55:129-150

10. Büyükgüzel E, Tunaz H, Stanley D, Büyükgüzel K (2007) Eicosanoids mediate Galleria mellonella cellular immune response to viral infection. J Insect Physiol 53:99-105

11. Casteels-Josson K, Zhang W, Capaci T, Casteels P, Tempst P (1994) Acute transcriptional response of the honeybee peptideantibiotics gene repertoire and required post-translational conversion of the precursor structures. J Biol Chem 269:2856928575

12. Cerenius L, Lee BL, Söderhall K (2008) The proPO-system: pros and cons for its role in invertebrate immunity. Trends Immunol 29:263-271

13. Chen YP, Siede R (2007) Honey bee viruses. Adv Virus Res 70:33-80

14. Christian P, Carstens E, Domier L, Johnson J, Johnson K, Nakashima N, Scotti P, van der Wilk F (2005) Dicistroviridae. In: Fauquet CM, Mayo MA, Maniloff J, Desselberger U, Ball LA (eds) Virus Taxonomy VIII. Elsevier Academic Press, San Diego, pp 783-788

15. Costa A, Jan E, Sarnow P, Schneider D (2009) The Imd pathway is involved in antiviral immune responses in Drosophila. PLoS One. doi:10.1371/journal.pone.0007436

16. Deddouche S, Matt N, Budd A, Mueller S, Kemp C, GalianaArnoux D, Dostert C, Antoniewski C, Hoffmann JA, Imler J-L (2008) The DExD/H-box helicase Dicer-2 mediates the induction of antiviral activity in drosophila. Nat Immunol 9:1425-1432

17. de Miranda JR, Drebot M, Tyler S, Shen M, Cameron CE, Stoltz DB, Camazine SM (2004) Complete nucleotide sequence of Kashmir bee virus and comparison with acute bee paralysis virus. J Gen Virol 85:2263-2270

18. de Miranda JR, Cordoni G, Budge G (2010) The Acute bee paralysis virus-Kashmir bee virus-Israeli acute paralysis virus complex. J Invertebr Pathol 103:S30-S47

19. Dostert C, Jouanguy E, Irving $P$, Troxler L, Galiana-Arnoux D, Hetru C, Hoffmann JA, Imler J-L (2005) The Jak-STAT signaling pathway is required but not sufficient for the antiviral response of drosophila. Nat Immunol 6:946-953

20. Durmuş Y, Büyükgüzel E, Terzi B, Tunaz H, Stanley D, Büyükgüzel K (2008) Eicosanoids mediate melanotic nodulation reactions to viral infection in larvae of the parasitic wasp, Pimpla turionellae. J Insect Physiol 54:17-24

21. Evans JD, Aronstein K, Chen YP, Hetru C, Imler J-L, Jiang M, Kanost M, Thompson GJ, Zou Z, Hultmark D (2006) Immune pathways and defence mechanisms in honey bees Apis mellifera. Insect Mol Biol 15:645-656 
22. Fedorova AA, Azzami K, Ryabchikova EI, Spitsyna YE, Silnikov VN, Ritter W, Gross HJ, Tautz J, Vlassov VV, Beier H, Zenkova MA (2011) Inactivation of a non-enveloped RNA virus by artificial ribonucleases: honey bees and Acute bee paralysis virus as a new experimental model for in vivo antiviral activity assessment. Antiviral Res 91:267-277

23. Galiana-Arnoux D, Dostert C, Schneemann A, Hoffmann JA, Imler J-L (2006) Essential function in vivo for Dicer-2 in host defense against RNA viruses in drosophila. Nat Immunol 7:590-597

24. Genersch E, Aubert M (2010) Emerging and re-emerging viruses of the honey bee (Apis mellifera L.). Vet Res 41:54

25. Govan VA, Leat N, Allsopp M, Davison S (2000) Analysis of the complete genome sequence of Acute bee paralysis virus shows that it belongs to the novel group of insect-infecting RNA viruses. Virology 277:457-463

26. Honeybee Genome Sequencing Consortium (2006) Insights into social insects from the genome of the honeybee Apis mellifera. Nature 443:931-949

27. Horohov DW, Dunn PE (1983) Phagocytosis and nodule formation by hemocytes of Manduca sexta larvae following injection of Pseudomonas aeruginosa. J Invertebr Pathol 41:203-213

28. Hultmark D (2003) Drosophila immunity: paths and patterns. Curr Opin Immunol 15:12-19

29. Huszar T, Imler J-L (2008) Drosophila viruses and the study of antiviral host-defense. Adv Virus Res 72:227-265

30. Kieft JS (2009) Comparing the three-dimensional structures of Dicistroviridae IGR IRES RNAs with other RNA structures. Virus Res 139:148-156

31. Kitamura N, Semler BL, Rothberg PG, Larsen GR, Adler CJ, Dorner AJ, Emini EA, Hanecak R, Lee JJ, van der Werf S, Anderson CW, Wimmer E (1981) Primary structure, gene organization and polypeptide expression of poliovirus RNA. Nature 291:547-553

32. Laemmli UK (1970) Cleavage of structural proteins during the assembly of the head of bacteriophage T4. Nature 227:680-685

33. Lemaitre B, Hoffmann J (2007) The host defense of Drosophila melanogaster. Annu Rev Immunol 25:697-743

34. Liljas L, Tate J, Lin T, Christian P, Johnson JE (2002) Evolutionary and taxonomic implications of conserved structural motifs between picornaviruses and insect picorna-like viruses. Arch Virol 147:59-84

35. Maori E, Lavi S, Mozes-Koch R, Gantman Y, Peretz Y, Edelbaum O, Tanne E, Sela I (2007) Isolation and characterization of Israeli acute paralysis virus, a dicistrovirus affecting honeybees in Israel: evidence for diversity due to intra- and interspecies recombination. J Gen Virol 88:3428-3438

36. Moore NF, Kearns A, Pullin JS (1980) Characterization of Cricket paralysis virus-induced polypeptides in Drosophila cells. J Virol 33:1-9

37. Moore NF, Reavy B, Pullin JSK, Plus N (1981) The polypeptides induced in Drosophila cells by Drosophila C virus (strain Ouarzazate). Virology 112:411-416

38. Nakashima N, Sasaki J, Tsuda K, Yasunaga C, Noda H (1998) Properties of a new picorna-like virus of the brown-winged green bug, Plautia stali. J Invertebr Pathol 71:151-158

39. Nakashima N, Uchiumi T (2009) Functional analysis of structural motifs in dicistroviruses. Virus Res 139:137-147
40. Peng Y-SC, Mussen E, Fong A, Montague MA, Tyler T (1992) Effects of chlortetracycline of honey bee worker larvae reared in vitro. J Invertebr Pathol 60:127-133

41. Randolt K, Gimple O, Geissendörfer J, Reinders J, Prusko C, Mueller MJ, Albert S, Tautz J, Beier H (2008) Immune-related proteins induced in the hemolymph after aseptic and septic injury differ in honey bee worker larvae and adults. Arch Insect Biochem Physiol 69:155-167

42. Ryan MD, Flint M (1997) Virus-encoded proteinases of the picornavirus super-group. J Gen Virol 78:699-723

43. Sabatier L, Jouanguy E, Dostert C, Zachary D, Dimarcq J-L, Bulet P, Imler J-L (2003) Pherokine-2 and -3: two Drosophila molecules related to pheromone/odor-binding proteins induced by viral and bacterial infections. Eur J Biochem 270:3398-3407

44. Sánchez-Vargas I, Scott JC, Poole-Smith BK, Franz AWE, Barbosa-Solomieu V, Wilusz J, Olson KE, Blair CD (2009) Dengue virus type 2 infections of Aedes aegypti are modulated by the mosquito's RNA interference pathway. PLoS Pathog 5:e1000299

45. Sasaki J, Nakashima N, Saito H, Noda H (1998) An insect picorna-like virus, Plautia stali intestine virus, has genes of capsid proteins in the $3^{\prime}$ part of the genome. Virology 244:50-58

46. Schägger H, von Jagow G (1987) Tricine-sodium dodecyl sulfatepolyacrylamide gel electrophoresis for the separation of proteins in the range from 1 to $100 \mathrm{kDa}$. Anal Biochem 166:368-379

47. Schlüns H, Crozier RH (2007) Relish regulates expression of antimicrobial peptide genes in the honeybee, Apis mellifera, shown by RNA interference. Insect Mol Biol 16:753-759

48. Stanley DW, Miller JS (2006) Eicosanoid actions in insect cellular immune functions. Entomol Exp Appl 119:1-13

49. Tate J, Liljas L, Scotti P, Christian P, Lin T, Johnson JE (1999) The crystal structure of cricket paralysis virus: the first view of a new virus family. Nat Struct Mol Biol 6:765-774

50. Trenczek T (1998) Endogenous defense mechanisms of insects. Zoology 101:298-315

51. Ulvila J, Hultmark D, Rämet M (2010) RNA silencing in the antiviral innate immune defence-Role of DEAD-box RNA helicases. Scand J Immunol 71:146-158

52. van Munster M, Dullemanns AM, Verbeek M, van den Heuvel JFJM, Clérivet A, van der Wilk F (2002) Sequence analysis and genomic organization of Aphid lethal paralysis virus: a new member of the family Dicistroviridae. J Gen Virol 83:3131-3138

53. van Rij RP, Saleh M-C, Berry B, Foo C, Houk A, Antoniewski C, Andino R (2006) The RNA silencing endonuclease Argonaute 2 mediates specific antiviral immunity in Drosophila melanogaster. Genes Dev 20:2985-2995

54. Wang X-H, Aliyari R, Li W-X, Li H-W, Kim K, Carthew R, Atkinson P, Ding S-W (2006) RNA interference directs innate immunity against viruses in adult Drosophila. Science 312:452-454

55. Xi Z, Ramirez JL, Dimopoulos G (2008) The Aedes aegypti Toll pathway controls Dengue virus infection. PLoS Pathog 4:e1000098

56. Zambon RA, Nandakumar M, Vakharia VN, Wu LP (2005) The Toll pathway is important for an antiviral response in Drosophila. Proc Natl Acad Sci USA 102:7257-7262

57. Zambon RA, Vakharia VN, Wu LP (2006) RNAi is an antiviral immune response against a dsRNA virus in Drosophila melanogaster. Cell Microbiol 8:880-889 